Belgrade, Serbia

anab_88@yahoo.com

\title{
NEW EVIDENCE OF THE CULT OF EPONA IN VIMINACIUM
}

\begin{abstract}
During the excavation of the villa rustica from the $2^{\text {nd }}$ century on the site of Nad Klepeckom near Viminacium, a fragment of a so-called snake vessel with an applied medallion was discovered in one of the rooms of the building. The medallion bears a representation of the goddess Epona. This find is the second iconographic representation of Epona discovered in Viminacium so far. In terms of iconography, it bears a resemblance to a marble relief previously discovered in Viminacium, as well as to the representations of the goddess on artefacts from the surrounding provinces in the Balkans. Nevertheless, certain details of the scene have closer analogies among representations from Gaul and Germania. This medallion is the first representation of Epona on a snake vessel, which has, until now, been related to oriental and certain Roman cults (Mithra, Dionysus/Liber), and the vessel itself was produced in a local workshop. Since this pottery vessel was most likely used by the residents of the villa, it represents a testimony of household worship of the cult of Epona in Viminacium.
\end{abstract}

KEYWORDS: MOESIA SUPERIOR, VIMINACIUM, VILLA RUSTICA, 2ND CENTURY, EPONA, SNAKE VESSEL.

\section{INTRODUCTION}

Viminacium, the capital of the Roman province of Moesia Superior, was founded during the $1^{\text {st }}$ century AD on the right bank of the Mlava River, in the vicinity of its confluence with the Danube, near modern-day Kostolac. ${ }^{1}$ The territory on which Viminacium emerged used to be inhabited by the tribe of Scordisci Minor prior to the Roman conquest. The Celts inhabited the Danube basin

1 The article is the result of the project: Viminacium, Roman city and military camp - research of material and non-material culture of inhabitants by using the modern technologies of remote detection, geophysics, GIS, digitalization and $3 D$ visualization (no 47018), funded by The Ministry of Education, Science and Technological Development of the Republic of Serbia. in the $4^{\text {th }}$ century $\mathrm{BC}$ for the first time, while in the $3^{\text {rd }}$ century, as noted by the writers from the period of classical Antiquity - Justin, Athenaeus and Strabo, a faction of Gauls returned to and permanently inhabited the territory around the confluence of the Sava and Danube rivers after the attack on Delphi in $279 \mathrm{BC}$; the Scordisci tribe was also founded in this period (Gavrilović 2011: 250). According to Strabo, Viminacium was situated on the territory inhabited by the Scordisci Minor, who lived together with the Thracians (Papazoglu 1969: 210). The archaeological finds that testify to the presence of the Celts in this territory are numerous. The most important discovery is that of a Celtic necropolis researched on the site 


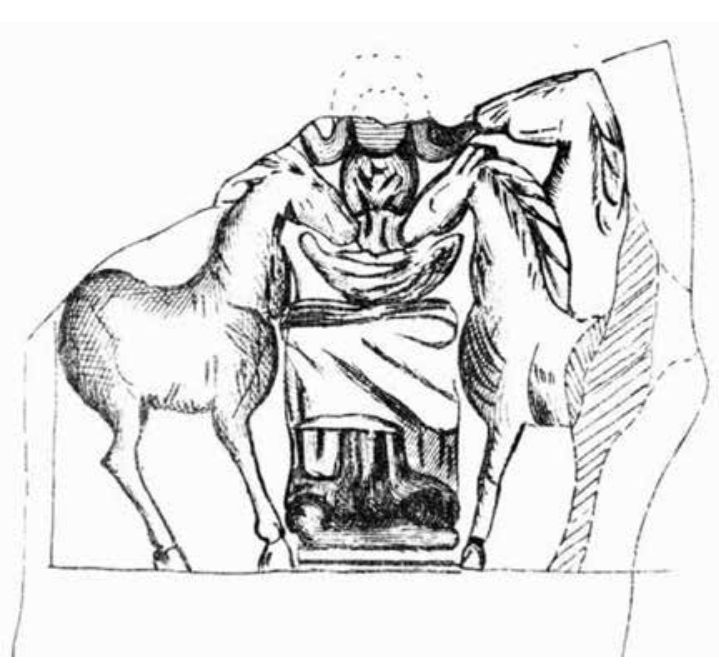

Fig.1: Drawing of the relief of Epona from Viminacium (after Gavrilović 2011: 259, Fig. 2).

of "Pećine", dated to the $4^{\text {th }}$ and early $3^{\text {rd }}$ century BC (Jovanović 1984; Јовановић 1985; Стојић и Јацановић 2008: 408-413). Apart from the above mentioned necropolis, there are also several more Celtic necropolises researched on the territory of Viminacium, as well as the related accidental finds: a part of a necropolis on the site of Rudine (Тапавички-Илић 2007), tomb finds on the site of Repnjak in Kostolac, tombs on the right bank of the Dunavac (Јацановић 1997), late La Tene pit graves on the site of Nad Lugom in the village of Drmno and late La Tene artefacts on the site of Čair (Спасић 1997; Спасић-Ђурић 2015: 18), while the largest portion of the finds comes from Kostolačko Ostrvo and Čibuklije (Стојић и Јацановић 2008: 162-167). The central Celtic settlement, that is, the oppidum, has not been archaeologically confirmed with any certainty, but recent excavations on the site of Mali Grad - Todića Crkva, carried out from 2007 to 2013, pointed to this area as the most probable location of the fortification from the $2^{\text {nd }}$ century $\mathrm{BC}$, inhabited until the middle or the second half of the $1^{\text {st }}$ century AD (Спасић-Ђурић 2015: 19). The remains of a Celtic settlement were also discovered during excavations on the site of "Nad Klepečkom", about $2 \mathrm{~km}$ east of the legionary camp, during excavations that lasted from 2010 until 2012 (Golubović, Mrđić 2011: 124, Fig. 7, Fig. 8.3).
Apart from the Scordisci, soldiers recruited from the region of Gaul appear in Viminacium after the Roman conquest, around the end of the $1^{\text {st }}$ century AD. Epigraphic finds with Celtic names or epithets which point to the persons of Celtic origin testify to the presence of a Celtic population (Gavrilović 2013: 177-179). Moreover, a large number of artefacts from the location of the Roman city (fibulae, weapons, jewellery and ceramics) is related to the Celts and testifies to a material and spiritual continuity, even during the Roman period (Gavrilović 2011: 253).

\section{CELTIC DEITIES ON THE TERRITORY OF MOESIA SUPERIOR}

The artefacts testifying to the Celtic presence in Viminacium are numerous. However, our knowledge of their spiritual and religious sphere is very modest, since the representations of Celtic deities are rare. Numerous pieces of evidence of Roman, oriental and Thracian cults have been discovered in Viminacium so far (Zotović 1996), while the only evidence of Celtic cults or deities is a marble relief portraying Epona (Fig. 1), dated to the $2^{\text {nd }}-3^{\text {rd }}$ century (Gavrilović 2011: 259, Fig. 2). This relief, discovered on the site of "Čair", that is, the location of the Roman city, was kept in the Museum of Požarevac until World War II, after which it disappeared. The cult of Epona in the province of Moesia Superior is also confirmed in the hoard from Branetic on Rudnik, dated to the end of the $2^{\text {nd }}$ century $A D$, where there is a silver plate with the inscription EPONE, while the goddess herself is represented on the handle of a silver patera, wearing a corona muralis on her head and holding a foal in her lap (Popović 1994: cat. 203). ${ }^{2}$ Epona's dedicants were most likely miners, blacksmiths or hirers who came

2 Certain authors maintain that the representation is actually a syncretism of Epona, Terra Mater and Orcia (Јовановић 2007: 36-39; Gavrilović 2013: 176). 


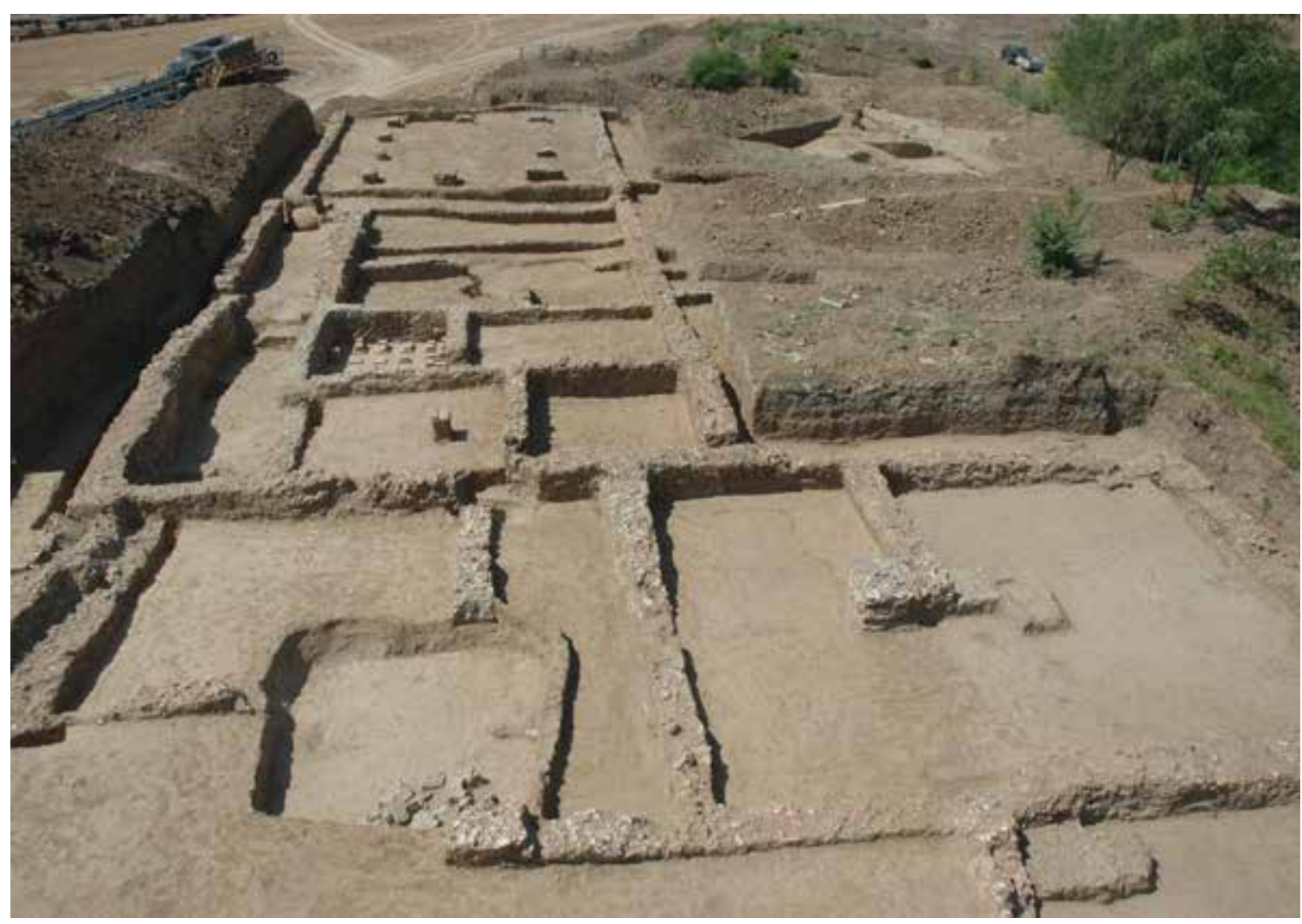

Fig.2: Roman villa rustica on the site Nad Klepečkom, Viminacium (after Jovičić, Redžić 2014: 54, Sl. 3).

from Gaul and worked in the silver and lead mines on Mt Rudnik (Поповић 1995: 153). The cult of the goddess Epona in the territory of our country is also noticeable indirectly, through the influence that iconographic representations of Epona had on the cult of the Danubian horsemen, i.e. on the representations of the central goddess which appears on the lead icons of that cult (Plemić 2013). This influence originally occurred on the border between Moesia Inferior and Dacia, from where it spread along the Danube to Moesia Superior, Pannonia Inferior and Superior, and was also observed in the workshops which produced lead icons in Viminacium, Singidunum and Sirmium (Plemić 2013: 69). A consecration to the female deity Dea Orcia, discovered on Avala, near Singidunum, should also be mentioned here, since there is a possibility that this was a Celtic goddess (Gavrilović 2013: 176).

Since evidence of the cult of Epona on the territory of Moesia Superior during the period of antiq- uity is scarce, we consider the find of a fragment of a ceramic vessel, discovered during the excavation of the large complex of a villa rustica ${ }^{3}$ in 2013 on the site of "Nad Klepečkom", several kilometres east of Viminacium (Jovičić, Redžić 2014), especially significant. The villa had a central courtyard, a western utility and eastern residential part in which the remains of the floor and wall heating system have been discovered (Fig. 2). The entire complex is dated to the period of the middle and second half of the $2^{\text {nd }}$ century. In the north-eastern, residential part of the villa, a fragment of a ceramic vessel with a medallion applied to it, containing an iconographic representation of the goddess Epona, was discovered in one of the rooms.

3 The research of the villa has not been completed. The dimensions of its researched area are $80 \times 31.5 \mathrm{~m}$; it consists of at least 24 rooms, and is the largest villa rustica researched in Viminacium so far. 


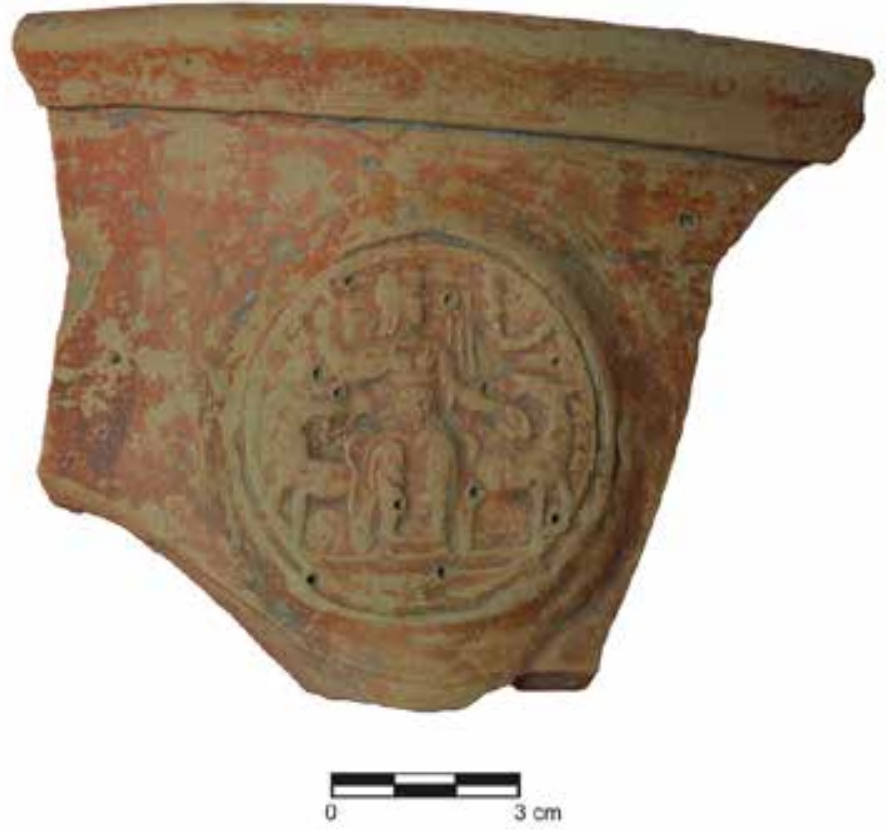

Fig.3: Fragment of the snake vessels from the villa rustica with depiction of Epona, site Nad Klepečkom, Viminacium.

CERAMIC VESSEL WITH APPLIED MEDALLION OF EPONA FROM ROMAN VILLA ON THE SITE OF NAD KLEPEČKOM/VIMINACIUM

A fragment of vessel discovered in one of the rooms of the villa rustica on the site of Nad Klepečkom was made of medium fine-texture clay, in a red fabric, Munsell: 2, 5YR-5/8, while the outer surface has a red slip (Fig. 3). The diameter of the vessel measures $24 \mathrm{~cm}$ and the diameter of the application itself is $5.5 \mathrm{~cm}$ (Fig. 4). According to the preserved part of the vessel, it is assumed that it belongs to a form whose production was confirmed in the workshop centre on the territory of Viminacium (Raičković 2007: 29, II/48, T. VI, sl. 59). A pot with two, or less frequently three handles, is one of the most numerous forms in the repertoire of the ceramic material of Viminacium. The discovered specimens are often ornamented using the barbotine technique, painting, stamping, but also with the application of ornaments. Since analogies can be found in Moesia Superior (Nikolić-Đorđević 2000: 85,
II/52), as well as in the neighbouring provinces (Brukner 1981: 41, T. 105/11-16; Popilian 1976: 91, Pl. XXXIX/399-404), it could be asserted that production was carried out in several local workshops. Within this form, the group of the so-called snake vessels draws special attention; their specific feature being the application of a relief ornament, most frequently together with vegetative or geometrical motifs rendered by stamping. In most cases, the relief ornament is placed on the neck of the vessel, while the snake is always applied on the handles and often on the body and rim of the pot too. Several authors have studied this category of ritual vessels, but the prevailing opinion is that they were used in the cults dedicated to oriental deities, primarily Mithra or Sabazios. Fragments of snake vessels were found, for example, as a part of the inventory in the third Mithraeum in the Carnuntum and dated to the second half of the $2^{\text {nd }}$ and the $3^{\text {rd }}$ century (Gugl, Kremer 2011: 171, Nr. 48). However, recent finds point to their belonging to the cult of Liber, the god of fertility, and his companion Libera (Cvjetićanin 2001: 95-96), which is also testified by the fragment of a snake vessel 

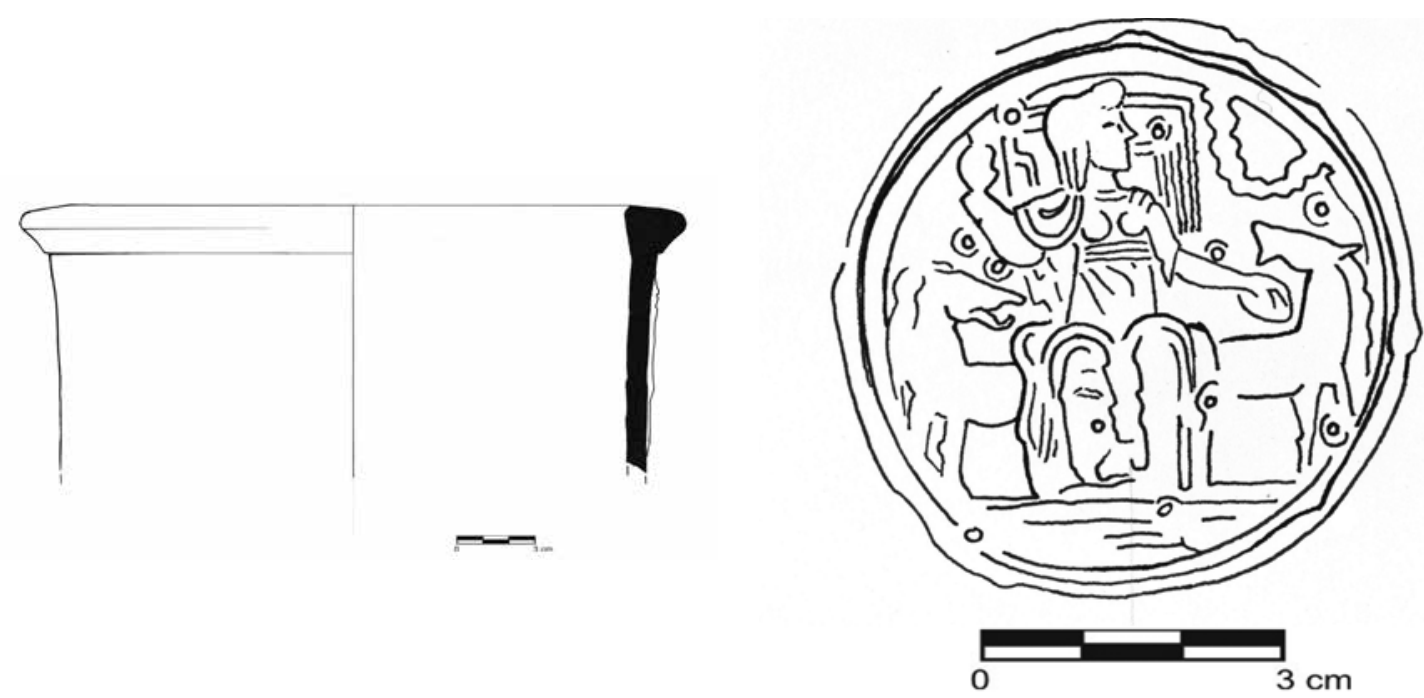

Fig.4: Drawing of the snake vessels fragment (left) and applied medallion with depiction of Epona (right), site Nad Klepečkom, Viminacium.

from Viminacium (Fig. 5), discovered on the site of Pećine, within the workshop centre, on which this deity is represented (Raičković, Redžić, Milovanović 2006: 70, T. II). We assume that pottery fragment from the site of Nad Klepečkom with representation of goddess Epona belongs to this type of ritual vessels.

The central figure, dominating the application, is the goddess. She is sitting on a throne represented by vertical curved lines. Epona is dressed in a long tunic (chiton) girdled below the chest. The robe is defined by oblique lines in the region of her stomach. Over the tunic, she is wearing a long himation (palla), which covers her arms and reaches her feet and is richly draped around the knees. The goddess's legs stand apart, the knees are separated and the feet are on the pedestal (suppedaneum). Her left hand is raised towards an animal and she is holding a patera in it. The part of the arm covered by the robe is clearly discernible from the rest of her arm, which is bare. The right hand is raised, and the goddess is holding a small object in it, but it cannot be identified with certainty, since it was rendered in a simplified manner due to the lack of space. The goddess's head is shown in profile. It is turned to the left, and the only clearly visible details are the nose and the eye. The hair most likely has a middle parting, though it is possible that there is a representation of a crown or a veil on the top of her head, since it is flat. Below it, thick locks falling down to the shoulders are visible. The horses flanking the Epona are considerably smaller than the goddess, so these are most likely the representations of foals. Their bodies are directed away from the goddess, but their heads are turned towards her, while the rear legs are behind the throne on which the goddess is seated. Behind the head of the foal on the right side, there is a representation of mane, which can be noticed behind the foal on the left, too. The horses have no headstall or reins, they are depicted completely without equipment. A motif of an arching garland is depicted in the upper right part.

\section{THE CULT OF EPONA IN THE ROMAN PERIOD}

During the Roman period, Epona was the most popular Celtic deity, appearing on the largest number of artefacts (Linduff 1979). The goddess's name stems from the Celtic word for a horse, i.e. mare - epos (Monaghan 2004: 249). Epona is the protectress of horses, mares, foals and everything related to horses, a goddess of fertility, an iatric deity and the protectress of the dead (Boucher 

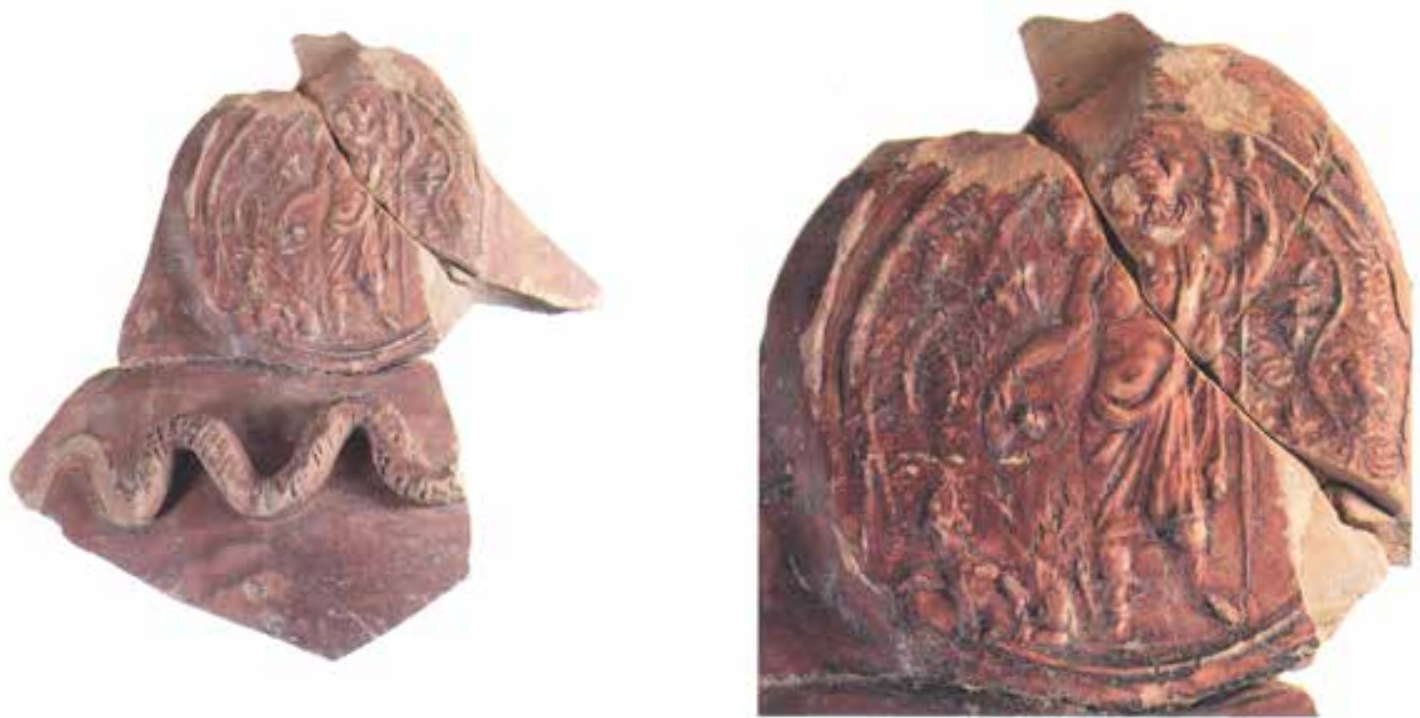

Fig.5: Fragment of the snake vessels from Pećine/Viminacium with depiction of Liber/Bachus (Спасић-Ђурић 2015: 98, Sl. 99).

1990: 997). As a horse goddess, Epona is also the protectress of equestrianism, muleteers and horse stables, and of carriages, transport and trade, that is - all occupations related to horses (Turcan 1996: 23). On the iconographic artefacts, Epona is depicted either riding a horse, mare or a foal, which is typical of the region of Gaul and Germania (Fig. 6), or sitting on a throne flanked by two (or more) horses (Fig. 7), which represents the so-called "Imperial" type, predominant in the Danube basin and across the Empire (Boucher 1990: 986-991; Euskirchen 1993: 622-676). Epona is the goddess of fertility and vegetation, so in iconography, a wheat ear, the horn of plenty (cornucopia), a basket with fruits and a patera from which she is feeding horses appear as her attributes. The representations from Gaul relate her to the underworld and a chthonic aspect, she protects the decedents and leads them on their journey from this world to the afterlife, so on these representations keys, dog and raven appear as her attributes (Green 1992b: 17-19). As a healing deity, Epona is connected to wells, lakes and thermal water springs (Linduff 1979: 833).

The cult of Epona is evident across the Empire, from Great Britain to the Balkans, and the finds correspond to the distribution of the Roman legions in Europe and are, in most cases, connected to legionary forts. The iconographic artefacts are primarily made of stone, or less frequently of bronze and terracotta and, together with consecrations, date back to the $2^{\text {nd }}$ and $3^{\text {rd }}$ century. The finds dedicated to Epona are most frequent in northern Gaul (Burgundy, Metz-Trier, Meuse), in the Rhine basin and in both Germanias (Linduff 1979: 821; Green 1992b: 16, map 4; Bucher 1990: 985-999). According to the epigraphic inscriptions, in the legionary forts on the Rhine and Danube, Epona was recognised and worshipped primarily as a military goddess, the protectress of the cavalry and horses, who protected the soldiers on the battlefield (Green 1992b: 16). The cult had an official character, and its dedicants were mostly the legionaries, specifically, those from the cavalry regiments predominantly comprised of Celts and, later, Germans. At first, the cult was observed by the population from Celtic regions, that is, individuals and groups from the Celtic ethnic corps. However, over the course of time it spread among the civilian population belonging to other ethnic groups, but related to horses and equestrianism. Epona was worshipped in homes and sanctuaries, for example in Burgundy, in Ebtrains-sur-Nohan (Nievre), where one temple dedicated to Epona 
has been discovered (Green 1992b: 16). The goddess's popularity also stems from her universal character as a mother goddess who is a symbol of fertility, life and death, looking after prosperity, abundance, health and regeneration, and as the protectress of people in the afterlife (Green 1992a: 205-207). Epona also became a member of the Roman pantheon, which was made official in Rome, where Epona was the only Celtic deity which had a public holiday every year on December 18 (Duval 1976: 50; Green 1992b: 19). Horses and mules were decorated in honour of Epona, and Celts never ate horse meat out of respect for her, which also spread as a taboo across the European cuisines in later periods (Monaghan 2004: 249).

\section{DISCUSSION}

The most frequent type of representations of Epona on the artefacts from the Roman period is those in which the goddess is riding a horse; this is characteristic of Gaul and Germania (Linduff 1979: 823, Typ A; Euskirchen 1993: 625-662, Typ $\mathrm{I}-\mathrm{V})$. However, that type is rare in our region and

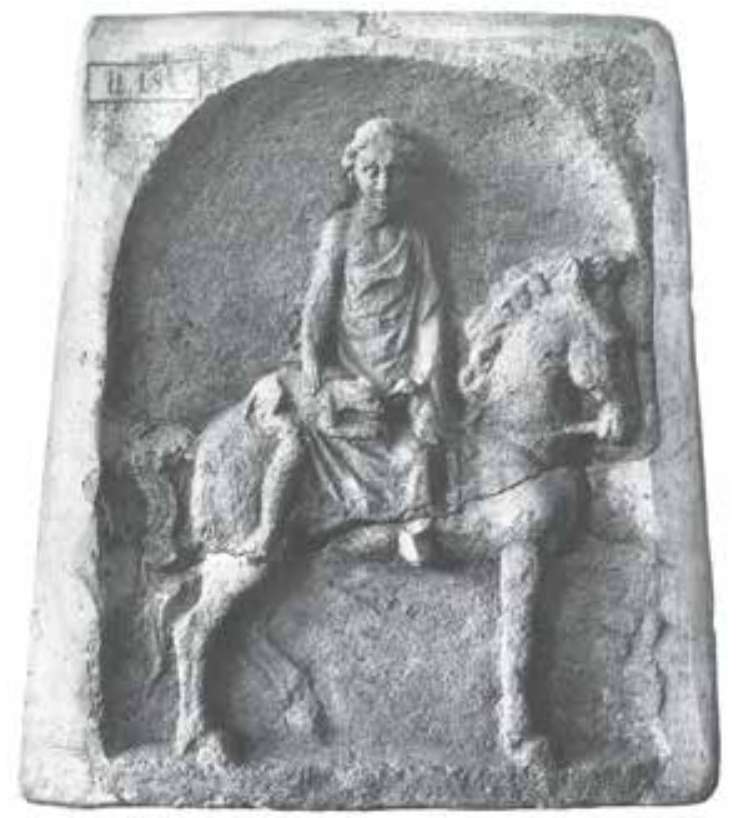

Fig.6: The so-called equestrian type of Epona's representations, Alt-Trier (after Euskirchen 1993: 647, Abb. 16).

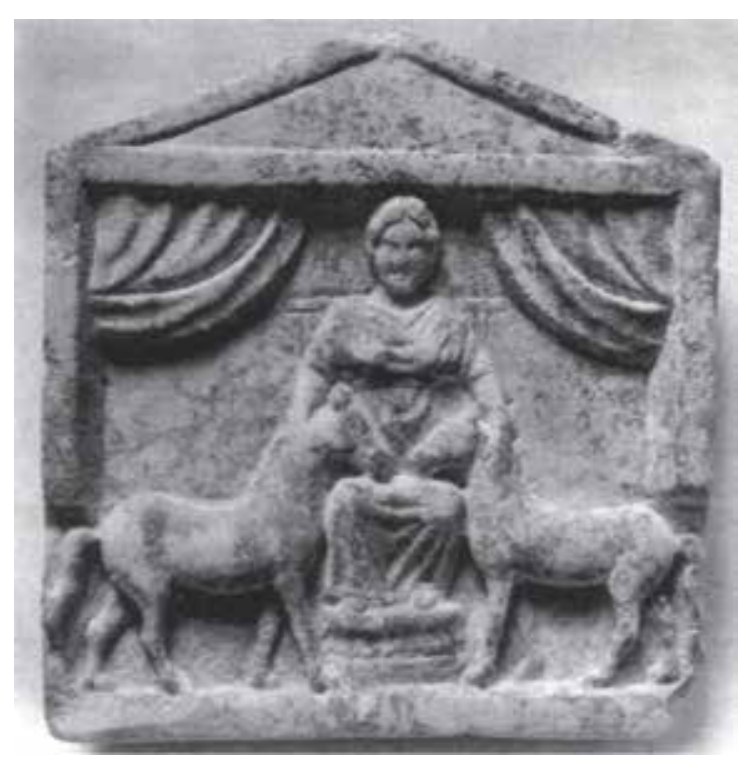

Fig.7: The so-called Imperial type of Epona's representations, Relief of Epona from Museum of Fine Arts, Budapest (after Boucher 1990: 994, Nr. 207).

has only been identified on one silver plate from the hoard in Petrijanec (Šiša-Vivek, Leleković, Kalafatić 2005: 236, slika 7). On the application of the snake vessel from the site of Nad Klepečkom there is a representation of the goddess Epona which belongs to the type in which she is sitting on a throne, flanked by horses, i.e. the "Imperial" type, typical of the Danubian provinces of the Empire, which appears from the $2^{\text {nd }}$ century AD (Linduff 1979: 823, Typ B; Boucher 1990: 986-991; Euskirchen 1993: 662-676, Typ VI-VII, Kat. Nr. 212245). The only artefact dedicated to Epona which has been discovered in Viminacium so far (Gavrilović 2011: 259, Fig. 2), but also the finds from across the Balkans, in the neighbouring provinces, such as the relief from Koprno in Croatia (Cambi 2002: 207, Fig. 1.), two reliefs from Tibiscum in Dacia (Timoc 1997: 115-117, Fig. 1, 2), a relief from Thessaloniki (Boucher 1990: 994, Nr. 206), a relief from the Museum of Fine Arts in Budapest (Boucher 1990: 994, Nr. 207) and the relief from Harletz/Augustae in Moesia Inferior (Euskirchen 1993: 675, Kat. Nr. 242) belong to this type. Nevertheless, all of the above mentioned artefacts from the surrounding provinces belong to a sub variant 


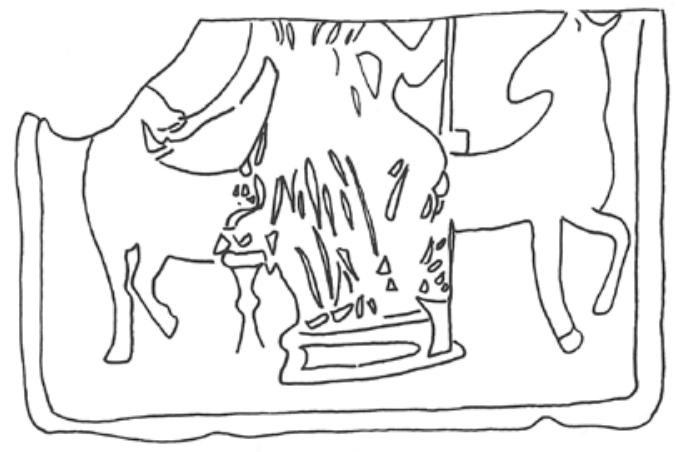

Fig.8: Drawing of the relief of Epona from Ostia (after Euskirchen 1993: 674, Kat. Nr. 238, Abb. 33.2).

of the type in which the horses are represented facing the goddess (Euskirchen 1993: 665-669, Typ VI, Variante 1), while the representation on the relief from Viminacium shows horses turned away from the goddess so, according to Euskirchen, it belongs to sub variant 3 (Euskirchen 1993: 671674, Typ VI, Variante 3). This sub variant appears on a brick fragment from Ostia (Italia) (Fig. 8), a bronze sculpture from Muri in Switzerland (Raetia), reliefs from Limbach in Saarland (east Gaul), Köngen (Fig. 9) and Öhrningen (Germania Superior) (Euskirchen 1993: Kat. Nr. 233-238) and on a gemstone held in the National Museum of Denmark, in Copenhagen (Fig. 10) (Boucher 1990: 994, Nr. 200a). These finds are dated to the end of the $2^{\text {nd }}$ or the very beginning of the $3^{\text {rd }}$ century $\mathrm{AD}$, which also corresponds to the period to which the fragment of a snake vessel with a representation of Epona from the villa rustica in Viminacium was dated. On four of the six above mentioned artefacts, the goddess is either feeding the horses from a basket or stroking their manes. Hence, the specimen from Ostia (Euskirchen 1993: Kat. Nr. 238) and the gemstone from Copenhagen are direct analogies with our specimen, since they represent the goddess with her right arm outstretched towards a foal she is feeding, while in her raised left hand she is holding a stick, or a sceptre on the specimen from Ostia, and a horn of plenty on the gemstone from Copenhagen. The difference with the representation from Viminacium is that in it, the left hand is outstretched towards the foal and in her right hand the goddess is holding an object. Such positioning of the hands is more frequent on the finds which belong to the Equestrian type than on those belonging to the Imperial type. The object that Epona is holding in her raised right hand cannot be identified easily. It cannot be determined with certainty whether it is a cornucopia or a stick/ sceptre, since the representation of the object is schematised, i.e. due to the lack of space on the applied medallion, the craftsman could not render a detailed representation of the object. The hand is raised up high, which leads us to believe that it could be a sceptre.

On the application from the snake vessel from the villa in Viminacium, the goddess's body is depicted en face, while the head is shown in profile. In most of the specimens belonging to this sub variant, both the body and the face of the goddess are shown en face, while only the specimen from Copenhagen shows the goddess in profile, so the representation on the snake vessel from Viminacium is a combination of these two types. The goddess's head shown in profile is more common on artefacts belonging to the Equestrian type. The horses, i.e. foals, on the medallion are represented directed away from the goddess, but their heads are turned towards Epona. On the specimens belonging to this type, the horses' heads are turned

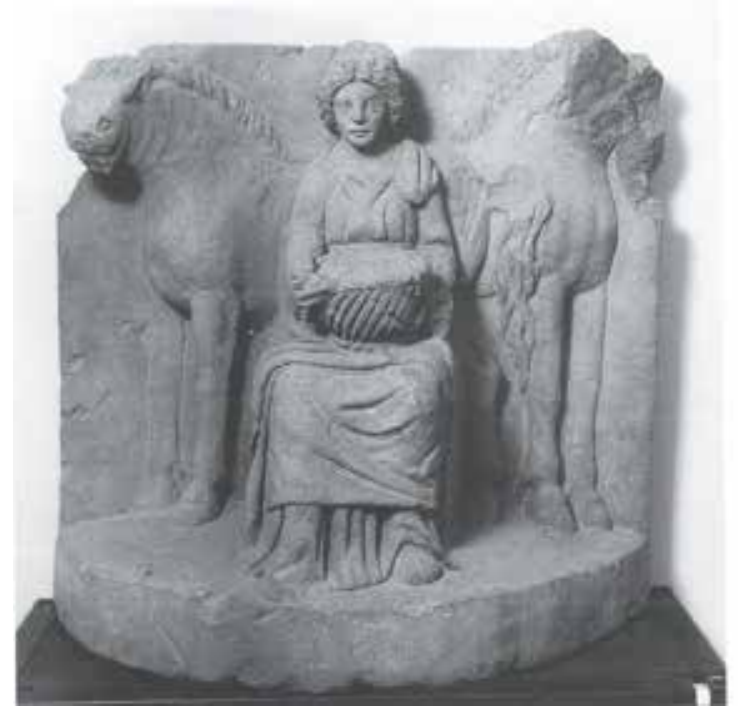

Fig.9: Relief of Epona from Köngen (after Euskirchen 1993: 672, Kat. Nr. 236, Abb. 31). 


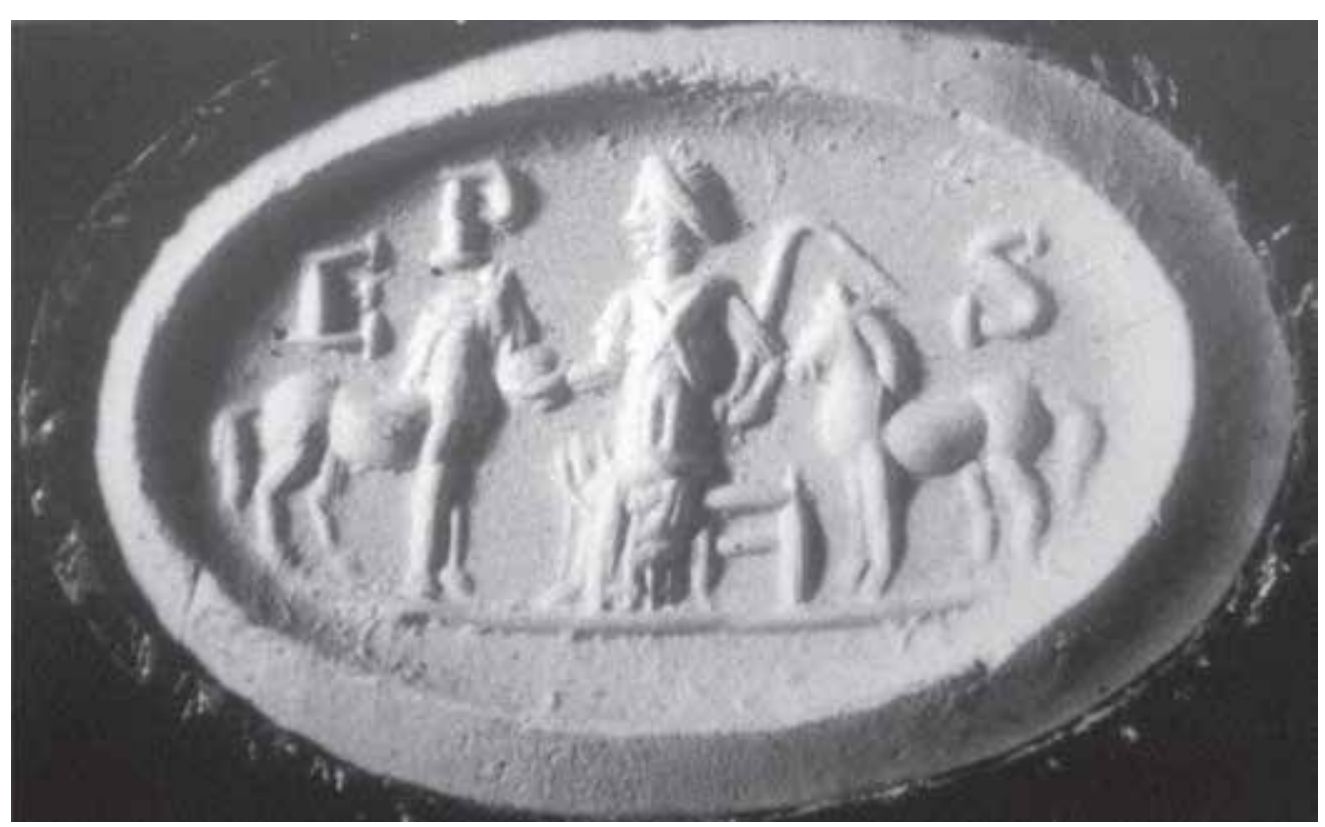

Fig.10: Carnelian gem with the representation of Epona, National Museum, Copenhagen (after Boucher 1990: 994, Nr. 200a).

away from the goddess, or shown en face, so the only analogy with our medallion, when it comes to the representation of the horses, can, once again, be found in the specimen from Ostia.

The garland in the upper right corner of the representation on the medallion remains a mystery. On certain reliefs, curtains appear in the corners of the scene itself, as is the case with the specimens from Budapest (Boucher 1990: 994, Nr. 207) and Rome (Schleiermacher 1932: Taf. 15). The garland on the specimen from Viminacium could be an imitation of these representations, since there was not enough space on the medallion to depict the other, symmetrical curtain in the opposite corner, which is absent for this reason. However, the garland and the curtains in the scenes from Budapest and Rome are not represented in the same manner - the garland has imbostures, which could represent a rose wreath. This is possibly pointed to by Apuleius in his "Metamorphoses", where he notes that in Thessaly, the icons of the goddess Epona held in the stables were decorated with rose garlands (Apuleius, Metamorphosis, III, 48). Therefore, the garland on our medallion could be a schematised rose garland, but there are no iconographic analogies for it.

The representations of Epona on ceramic ves- sels are extremely rare. The only analogies among the discovered materials are found on a fragmented bowl from Triere, rendered in the terra sigilata technique (Ebermann 2015: 13, Abb.1) and on a ceramic medallion from Lectoure (Euskirchen 1993: 663, Kat. Nr. 210). However, the reliefs on the fragments from Triere and Lectoure depicting Epona belong to the artefacts of the Equestrian type, while the representation of the goddess on the ceramic vessel from Viminacium belongs to the so-called Imperial type of representation. If we observe the relief representations of Epona, we can conclude that there are no regularities in the iconographic representation of the goddess, i.e. that a certain material the artefacts are made of does not necessarily imply a specific manner in which the relief depicting the goddess was rendered.

All of the finds of ceramic vessels with applied snakes discovered so far are related to certain oriental or Roman cults, which is not the case with the newly discovered specimen of a ceramic vessel from the villa east of Viminacium. Interestingly, all of the specimens from the territory of Viminacium come either from the settlement layers or from the funerary, i.e. utility units (Raičković, Redžić, Milovanović 2006). Since these vessels 
do not belong to a specific sanctuary, they can be the confirmation of a private, house cult, taking into account the symbolism of the snake as the protectress of the home (Vámos 2009: 538). It is assumed that the cult of the Celtic deity was close to the residents of the villa so, bearing that in mind, we can interpret a fragment of a ritual vessel with a representation of Epona, which had the role of a family protectress, as possibly being of Gaulish origin. There is also a possibility that the owner of the villa in Viminacium could have been a military veteran who saw his military service in the cavalry, since it is known that the soldiers from these regiments were often Epona's dedicants.

The interpretation of the snake vessels, as well as their dedication to oriental cults, or the deities of the Roman Pantheon, whose primary bearers were the soldiers of the regiments from the East, was exclusive. The recent find of the ceramic medallion can offer an additional interpretation of the ritual vessels, related to the cult of goddess Epona.

\section{CONCLUSION}

A fragment of a ceramic vessel with a representation of the Celtic goddess, beside the previously discovered stone relief, additionally confirms the observance of the cult of Epona in Viminacium in the $2^{\text {nd }}$ century. The special importance of this object is reflected in the fact that this time the context of the find is known. It represents a unique specimen among snake vessels, opening a new chapter in their interpretation. Since the representation is found on a ritual vessel used in certain rites, this is most likely confirmation of a house cult, observed by the residents of the villa. Observing only the applied medallion with the representation of the goddess, we could conclude that it was created under the influence of the established iconographic schemes from the stone artefacts of the so-called Imperial type which are, at the same time, the most common type of Epona representation in the Danube basin.
Arheologija i prirodne nauke (Archaeology and Science) is an Open Access Journal. All articles can be downloaded free of charge and used in accordance with the licence Creative Commons - Attribution-NonCommercial-NoDerivs 3.0 Serbia (https://creativecommons.org/licenses/bync-nd/3.0/rs/.

Časopis Arheologija i prirodne nauke je dostupan u režimu otvorenog pristupa. Članci objavljeni u časopisu mogu se besplatno preuzeti sa sajta $i$ koristiti u skladu sa licencom Creative Commons - Autorstvo-Nekomercijalno-Bez prerada 3.0 Srbija (https://creativecommons.org/licenses/bync-nd/3.0/rs/.

\section{BIBLIOGRAPHY}

\section{Ancient sources}

\section{Apuleius - Metamorphosis}

The Metamorphosis or Golden Ass, Translated by Thomas Taylor, London 1822.

\section{Liiterature}

\section{Boucher, S. 1990}

Epona, in: Lexicon Iconographicum Mythologiae Classicae V/1, L. Kahil, (ed.), Zurich / Munchen: Artemis, 985-998.

\section{Brukner, O. 1981}

Rimska keramika u jugoslovenskom delu provincije Donje Panonije, Dissertationes et monographiae XXIV, Beograd: Pokrajinski zavod za zaštitu spomenika kulture SAP Vojvodine, Savez arheoloških društava Jugoslavije.

\section{Cambi, N. 2002}

Bilješke uz reljef Epone iz Koprna, VAMZ XXXV: 205-214.

\section{Cvjetićanin, T. 2001}

Snake vessels from Diana, in: Die Archäologie und Geschichte der Region des Eisernen tores 
zwischen 106-275 N. Chr. (Kolloquium in Drobeta-Turnu Severnin, 1.-4. Oktober 2000), M. Zahariade (ed.), Bucureşti: Institutul de Tracologie (Romania), 93 - 104.

\section{Duval, P. M. 1976}

Les dieux de la Gaule, Paris: Payot.

\section{Ebermann, E. 2015}

Die Gallo-Römische Göttin Epona auf Reliefverzierten Schüsseln des 2./3. Jh. N. Chr. aus Trier, Saalburg Jahrbuch 58 (2014): 13-24.

\section{Euskirchen, M. 1993}

Epona, Berichte der Romisch-Germanischen Kommission 74: 607-838.

\section{Gavrilović, N. 2011}

Relief of Epona from Viminacium - Certain Considerations about the Cult of Epona in Central Balkans, in: Keltische Götternamen Als Individuelle Option? (Akten des 11. Internationalen Workshops „Fontes Epigraphici Religionum Celticarum Antiquarum" vom 19-21. Mai 2011 an der Universität Erfurt), W. Spickermann (Hgg.), Rahden: Marie Leidorf GmbH, 250-261.

\section{Gavrilović, N. 2013}

Traces of Celtic Population and Beliefs in the Roman Provinces of the Central Balkans, in: Théonymie celtique, cultes, interpretatio / Keltische Theonymie, Kulte, interpretatio (X. Workshop F.E.R.C.AN., Paris 24.-26. Mai 2010), A. Hofeneder and P. de Bernardo Stempel (Hgg.), Mitteilungen der Prähistorischen Kommission Band 79, Wien: Verlag der Österreichische Akademie der Wissenschaften, 175-182.

\section{Golubović, S. and Mrđić, N. 2011}

Territory of Roman Viminacium From Celtic to Slavic Tribes, Anodos. Studies of the Ancient World 10/2010: 117-125.

\section{Green, M. 1992a}

Animals in Celtic life and myth, London and New York: Routledge.

\section{Green, M. 1992b}

Symbol and Image in Celtic Religious Art, London / New York: Routledge.

\section{Gugl, C. and Kremer, G. 2011}

Soldaten, Bürger, Kaiser - Mithras in Carnuntum, in: Götterbilder - Menschenbilder. Religion und Kulte in Carnuntum, F. Humer und G. Kremer, (Hgg.), Wien: Amt Der NÖ Landesregierung, Archäologischer Park Carnuntum, 163-174.

\section{Husar, A. 1995}

The Celtic Gods in Roman Dacia, Acta Musei Napocensis XXXII: 85-94.

\section{Јацановић, Д. 1997}

Каснолатенски локалитет „Дунавац” у Костолцу, Гласник САД 13: 127-132.

(Jacanović, D. 1997

Kasnolatenski lokalitet „Dunavac” u Kostolcu, Glasnik SAD 13: 127-132.)

\section{Јовановић, А. 2007}

Огледи из античког култа и иконографије, Београд: Filozofski fakultet, Centar za arheološka istraživanja.

(Jovanović, A. 2007

Ogledi iz antičkog kulta i ikonografije, Beograd: Filozofski fakultet, Centar za arheološka istraživanja.)

\section{Jovanović, B. 1984}

Les sépultures de la nécropole céltique de Pećine pres de Kostolac, Etudes Celtiques XXI: 63-93.

\section{Јовановић, Б. 1985}

Некропола на Пећинама и старије гвоздено доба Подунавља, Старинар XXXVI: 13-18. 
(Jovanović, B. 1985

Nekropola na Pećinama i starije gvozdeno doba Podunavlja, Starinar XXXVI: 13-18.)

Jovičić, M. i Redžić, S. 2014

Istraživanje antičke vile rustike na lokalitetu $\mathrm{Nad}$ Klepečkom (Viminacijum) u 2013. godini, u: $A r-$ heologija u Srbiji: projekti Arheološkog instituta u 2013. godini, D. Antonović, (ur.), Beograd: Arheološki institut, 54-59.

Linduff, K. 1979

Epona: a Celt among the Romans, Collection Latomus 38: 817-837.

Monaghan, P. 2004

The encyclopedia of Celtic Mythology and Folklore, New York: Facts On File, Inc.

Munsell 2012

Munsell Soil-Color Charts

Nikolić-Đorđević, S. 2000

Antička keramika Singidunuma, Singidunum 2: 11-244.

\section{Papazoglu, F. 1969}

Srednjobalkanska plemena u predrimsko doba (Tribali, Autarijati, Dardanci, Skordisci i Mezi), Djela 30, Centar za balkanološka ispitivanja 1, Sarajevo: Akademija nauka i umjetnosti Bosne i Hercegovine.

\section{Plemić, B. 2013}

Contribution to the Study of the Danubian Horsemen Cult: Iconographic Syncretism of the Danubian Goddess and Celtic Fertility Deities, Archaeologia Bulgarica XVII, 2 (2013): 59-72.

\section{Popilian, G. 1976}

Ceramica Romană din Oltenia, Craiova: Scrisul Românsec.

\section{Поповић, И. 1995}

Почеци локалне производње сребрног посуђа у Горњој Мезији, у: Радионице и ковнице сребра, Поповић, И., Цвјетићанин, Т. и БорићБрешковић, Б. (ур.), Београд: Народни музеј, 145-161.

(Popović, I. 1995

Počeci lokalne proizvodnje srebrnog posuđa u Gornjoj Meziji, u: Radionice i kovnice srebra, Popović, I., Cvjetićanin, T. i Borić-Brešković, B. (ur.), Beograd: Narodni muzej, 145-161.)

\section{Поповић, И. (ур.) 1994}

Античко сребро у Србији, Београд: Народни музеј.

(Popović, I. (ur.) 1994

Antičko srebro u Srbiji, Beograd: Narodni muzej.)

Raičković, A., Redžić, S. i Milovanović, B. 2006 Posude sa apliciranim zmijama iz Zanatskog centra, Arheologija i prirodne nauke 2: 69-76.

\section{Raičković, A. 2007}

Keramičke posude Zanatskog centra iz Viminacijuma, Monographs 3, Beograd: Centar za nove tehnologije, Arheološki institut.

\section{Спасић, Д. 1997}

Прилог проучавања традиције Скордиска у Виминацијуму, Гласник САД 13: 33-45.

(Spasić, D. 1997

Prilog proučavanja tradicije Skordiska u Viminacijumu, Glasnik SAD 13: 33-45.)

\section{Спасић-Ђурић, Д. 2015}

Град Виминачијум, Пожаревац: Народни музеј Пожаревац.

(Spasić-Đurić, D. 2015

Grad Viminacijum, Požarevac: Narodni muzej Požarevac.)

Стојић, М. и Јацановић, Д. 2008

Пожсаревач: културна стратиграфија праисторијских локалитета, Археолошка грађа 
Србије IV, Београд: Археолошки институт Пожаревац: Народни музеј.

(Stojić, M. i Jacanović, D. 2008

Požarevac: kulturna stratigrafija praistorijskih lokaliteta, Arheološka građa Srbije IV, Beograd: Arheološki institut - Požarevac: Narodni muzej.)

\section{Schleiermacher, W. 1932}

Studien zu den Göttertypen der römischen Rhein Provinzen, Bericht der Romisch-Germanichen Kommission 23: 109-143.

Šiša-Vivek, M., Leleković T. i Kalafatić H. 2005 Ostava rimskog novca i srebrnog posuđa iz Petrijanca, Opuscula Archaeologica 29: 231-247.

Тапавички-Илић, М. 2007

Келтски гробови са Рудина у Старом Костолцу, Гласник САД 23: 245-252.

(Tapavički-Ilić, M. 2007

Keltski grobovi sa Rudina u Starom Kostolcu, Glasnik SAD 23: 245-252.)

\section{Turcan, R. 1996}

The Cults of the Roman Empire, Oxford: Blackwell.

\section{Vàmos, P. 2009}

Schlangengefäße in Aquincum, in: Ex officina... Studia in honorem Dénes Gabler, B. Szilvia, (ed.), Győr: Mursella Régészeti Egyesület, 537-557.

\section{Zotović, Lj. 1996}

Der Paganismus in Viminacium, Старинар 47: 127-137.

(Zotović, Lj. 1996

Der Paganismus in Viminacium, Starinar 47: 127-137.)

\section{REZIME NOVI DOKAZI O KULTU EPONE NA VIMINACIJUMU}

Prilikom istraživanja antičke vile rustike iz II veka n.e. koja se nalazi istočno od grada Viminacijuma, pronađen je fragment keramičke posude koji je izazvao posebnu pažnju. Naime, radi se o keramičkom loncu sa apliciranim medaljonom na kome je predstavljena keltska boginja Epona. Kelti su na prostoru Viminacijuma $u$ trenutku rimskog osvajanja predstavljali starosedeoce, a brojni arheološki nalazi potvrđuju njihovo prisustvo i tokom rimskog perioda. Nalazi koji svedoče o rasprostranjenosti kulta Epone na prostoru provincije Gornje Mezije su izuzetno retki, pa je stoga značajno predstaviti ovakav jedan primerak koji potvrđuje zastupljenost kulta posvećenog boginji Eponi, pored već poznatog kamenog reljefa koji je pronađen u Viminacijumu. Epona je kao zaštitnica konja i konjaničkih veština u najvećem broju slučajeva poštovana od strane vojnika, pa je u početku sam kult definisan kao vojni, da bi kasniji nalazi potvdili i civilni, odnosno kućni kult. Ikonografski prikaz Epone na posudi pripada tzv. „,imperijalnom tipu”, koji je najčešće zastupljen na Balkanu i u Podunavlju, gde je boginja prikazana kako sedi na tronu okružena konjima ili što je verovatnije, ždrebadima. Boginja je obučena u hiton i himation, a u levoj ruci drži pateru koju pruža ka jednom ždrebetu. Predmet koji boginja drži u desnoj, uzdignutoj ruci je teže protumačiti pošto je predstava šematizovana, ali se najverovatnije radi o štapu ili skiptru. Položaj konja, koji su okrenuti u smeru od boginje, izdvaja ovaj primerak od primeraka iz obližnjih provincija. Najbliže analogije našoj predstavi nalazimo na prikazima Epone iz Ostije, istočne Galije i Germanije.

Za primerak iz viminacijumske vile možemo reći da je bio sastavni deo kućnog kulta, s obzirom da je pronađen u rezidencijalnom delu objekta. Sve karakteristike keramičke posude ukazuju da se radi o formi čija je funkcija bila prvenstveno trpeznog karaktera, da bi grnčari u određenom 
trenutku započeli proizvodnju sakralnih posuda u okviru ovog oblika. Reč je naime o tzv. ,zmijskim posudama" čija se upotreba vezuje za kultove koje je rimska vojska donela sa Istoka, posvećenim božanstvima Mitri ili Sabaziju. Takođe, sakralne posude su tumačene i kao sastavni deo kulta boga Libera, što potvrđuje i jedan primerak posude sa apliciranim medaljonom tog božanstva pronađen na Viminacijumu. Viminacijumski primerak sa predstavom Epone, za koji smatramo da pripada upravo ovom tipu posuda, govori nam da je njihova primena imala značajnu ulogu i u kultu jednu keltske boginje. 